\title{
REPUTASI UNIVERSITAS, BIAYA KULIAH, FASILITAS PERKULIAHAN DAN KEPUTUSAN MAHASISWA MEMILIH PROGRAM STUDI MANAJEMEN UNIVERSITAS FLORES: STUDI PADA MAHASISWA PROGRAM STUDI MANAJEMEN ANGKATAN 2019
}

\author{
Oleh \\ 1) Yosafat Kristianus Bao \\ Mahasiswa Program Studi Manajemen \\ e-mail: fadilbao08@gmail.com \\ 2) Maria Helena Carolinda Dua Mea \\ Dosen Program Studi Manajemen \\ e-mail: helenaduamea@gmail.com
}

\begin{abstract}
ABSTRAK
Keputusan dalam menempuh pendidikan pada suatu jurusan merupakan tantangan besar di antara sebagian besar mahasiswa. Mereka akan mempertimbangkan dengan kondisi atau keadaan yang ada. Jika keadaan atau kondisi yang terlihat tidak sesuai dengan apa yang diharapkan maka akan terjadi keraguan yang berakibat pada keputusan untuk tidak memilih pada program studi yang diharapkan. Meskipun di dalam pengambilan keputusan untuk menempuh pendidikan pada suatu program studi diperlukan suatu pertimbangan, akan tetapi mahasiswa program studi Manajemen belum melakukan analisis mengenai program studi yang diambilnya.

Pendekatan penelitian yang digunakan adalah pendekatan kuantitatif. Dari hasil perhitungan diperoleh nilai thitung sebesar 19,794 dengan taraf signifikansi sebesar 0,000 atau nilai sig < 0,05 maka hipotesis pertama yang menyatakan "reputasi universitas berpengaruh terhadap keputusan mahasiswa memilih Prodi Manajemen di Universitas Flores" diterima. Dari hasil perhitungan diperoleh nilai thitung sebesar 0,887 dengan taraf signifikansi sebesar 0,377 atau sig > 0,05, dengan demikian hipotesis kedua yang menyatakan "biaya kuliah berpengaruh terhadap keputusan mahasiswa memilih Prodi Manajemen di Universitas Flores" ditolak. Dari hasil perhitungan diperoleh nilai thitung sebesar 5,295 dengan taraf signifikansi sebesar 0,000 atau nilai sig < 0,05 maka hipotesis ketiga yang menyatakan "fasilitas perkuliahan berpengaruh terhadap keputusan mahasiswa memilih Prodi Manajemen di Universitas Flores" diterima.
\end{abstract}

Kata kunci : Reputasi Universitas, Biaya Kuliah, Fasilitas Perkuliahan, dan Keputusan Mahasiswa

\begin{abstract}
The decision to study in a major is a big challenge among most students. They will consider the existing conditions or circumstances. If the circumstances or conditions seem not in accordance with what is expected, there will be doubts which result in the decision not to choose the expected study program. Although in making a decision to take education in a study program, a consideration is needed, however, students of the Management study program have not conducted an analysis of the study program they are taking.

The research approach used is a quantitative approach. From the calculation, the t-count value is 19.794 with a significance level of 0.000 or a sig value <0.05, the first hypothesis which states "the reputation of the university affects the student's decision to choose Management Study Program at the University of Flores" is accepted. From the calculation results, the t-count value is 0.887 with a significance level of 0.377 or sig> 0.05, thus the second hypothesis which states "tuition costs affect
\end{abstract}


REPUTASI UNIVERSITAS, BIAYA KULIAH, FASILITAS PERKULIAHAN DAN KEPUTUSAN MAHASISWA MEMILIH PROGRAM STUDI MANAJEMEN UNIVERSITAS FLORES: STUDI PADA MAHASISWA PROGRAM STUDI MANAJEMEN ANGKATAN 2019 1)Yosafat Kristianus Bao, ${ }^{2}$ )Maria Helena Carolinda Dua Mea

students' decisions to choose Management Study Program at the University of Flores" is rejected. From the calculation results, it is obtained that the t-count value is 5.295 with a significance level of 0.000 or a sig value $<0.05$, the third hypothesis which states "lecture facilities affect the student's decision to choose Management Study Program at the University of Flores" is accepted.

Keywords: University reputation, tuition fees, lecture facilities, and student decisions

\section{PENDAHULUAN}

Pengambilan keputusan (decision making) menurut Desmita (dalam (Evridawati et al., 2020) merupakan salah satu bentuk perbuatan berfikir dan hasil dari perbuatan itu disebut keputusan. Ini berarti bahwa dengan melihat bagaimana seseorang remaja mengambil suatu keputusan, maka dapat diketahui perkembangan pemikirannya. Menurut Anzizhan (dalam Evridawati et al., 2020) pengambilan keputusan adalah proses menentukan pilihan dari beberapa alternatif untuk menetapkan suatu tindakan dalam mencapai tujuan yang diinginkan. Keputusan calon mahasiswa dalam memilih perguruan tinggi bukanlah hal yang begitu saja terjadi, tetapi banyak pertimbangan calon mahasiswa sebelum memutuskan untuk melanjutkan studi di perguruan tinggi dan dipengaruhi oleh banyak faktor.

Universitas Flores adalah salah satu perguruan tinggi swasta yang ada di pulau Flores. Salah satu fakultas yang dimiliki oleh Universitas Flores yaitu Fakultas Ekonomi. Sebagai fakultas yang telah ada sejak tahun 1998, Fakultas Ekonomi telah menjadi tempat memperoleh ilmu oleh ribuan alumni mahasiswa di seluruh pulau Flores bahkan di luar pulau Flores dengan tiga program studi yakni Program Studi Manajemen, Program Studi Akuntansi, dan Program Studi Ekonomi Pembangunan dengan jenjang Pendidikan Strata-1. Fakultas Ekonomi sendiri hadir dengan mengusung pendidikan yang menghasilkan lulusan yang berkarakter dan memiliki daya saing di era revolusi industri 4.0 memberikan jawaban atas keinginan calon mahasiswa yang memiliki daya saing dan berkarakter ketika lulus nanti. Kehadiran Fakultas Ekonomi dengan visi 'Menjadikan Fakultas Yang Unggul dan Terpercaya Sebagai Mediator Budaya Dalam Bidang Ekonomi’ dan misi yang menghasilkan lulusan yang berkarakter dan memiliki daya saing di era revolusi industri 4.0 tidaklah cukup sebab hal itu tidak akan diterima dengan baik oleh calon mahasiswa. Oleh karena itu dalam menarik keputusan mahasiswa melanjutkan studi, Fakultas Ekonomi Universitas Flores terus melakukan inovasi dalam hal reputasi, biaya, dan fasilitas perkuliahan. 
REPUTASI UNIVERSITAS, BIAYA KULIAH, FASILITAS PERKULIAHAN DAN KEPUTUSAN MAHASISWA MEMILIH PROGRAM STUDI MANAJEMEN UNIVERSITAS FLORES: STUDI PADA MAHASISWA PROGRAM STUDI MANAJEMEN ANGKATAN 2019 -

1)Yosafat Kristianus Bao, ${ }^{2}$ )Maria Helena Carolinda Dua Mea

Mahasiswa program studi Manajemen berasal dari latar belakang yang berbeda-beda. Sehingga faktor-faktor yang mempengaruhi mereka ketika memilih jurusan juga berbeda tergantung dari setiap individu. Reputasi perguruan tinggi, biaya kuliah dan fasilitas perkuliahan merupakan beberapa faktor yang mempengaruhi mahasiswa dalam menempuh pendidikan pada program studi Manajemen. Ketiga faktor tersebut mempunyai hubungan yang erat kaitannya dengan pengambilan keputusan mahasiswa memilih program studi Manajemen. Dengan memahami variabel yang menjadi alasan mahasiswa mendaftar menjadi mahasiswa Program Studi Manajemen, diharapkan pihak program studi dapat mengelola prodi lebih baik sesuai apa yang menjadi keinginan mahasiswa dan para pemangku kepentingan.

Reputasi perguruan tinggi memiliki peranan yang penting bagi keunggulan suatu perguruan tinggi. Aktivitas Universitas Flores dalam menaikkan akreditasi universitas dan tiap program studi, menyelenggarakan event-event edukasi, dan merealisasikan Tri Dharma Perguruan Tinggi dapat meningkatkan nilai reputasi Universitas Flores.

Biaya pendidikan merupakan salah satu komponen instrumental yang sangat penting didalam penyelenggaraan pendidikan. Tanpa dukungan biaya pendidikan yang memadai, maka proses pendidikan tidak akan berjalan dengan baik. Beberapa jenis biaya yang terdapat di Universitas Flores saat ini adalah biaya SPP (Sumbangan Pembinaan Pendidikan) tetap, biaya unit kegiatan mahasiswa, biaya perpustakaan, biaya praktikum komputer, dana pembanguan, biaya kegiatan BEM (Badan Eksekutif Mahasiswa) dan biaya per SKS (Satuan Kredit Semester. Selain itu Universitas Flores juga memberikan beasiswa bagi mahasiswa yang berprestasi dalam hal akademik maupun non akademik.

Fasilitas yang disediakan oleh Universitas Flores adalah ruang kuliah yang memadai, perkuliahan menggunakan LCD proyektor, perpustakaan universitas, perpustakaan fakultas, laboratorium praktikum komputer, pengisian kartu rencana studi secara online, dan fasilitas melihat kartu hasil studi secara online. Selain itu fakultas juga menyediakan operator dalam membantu urusan akademik mahasiswanya.

Penelitian yang dilakukan oleh (Murti, 2019) menunjukkan bahwa brand image, promosi, biaya pendidikan mempengaruhi keputusan mahasiswa melanjutkan pendidikan. Sedangkan penelitian yang dilakukan oleh (Harahap et al., 2018) dan (Suriyani, 2016) menunjukkan reputasi universitas positif berpengaruh signifikan terhadap keputusan mahasiswa memilih 
REPUTASI UNIVERSITAS, BIAYA KULIAH, FASILITAS PERKULIAHAN DAN KEPUTUSAN MAHASISWA MEMILIH PROGRAM STUDI MANAJEMEN UNIVERSITAS FLORES: STUDI PADA MAHASISWA PROGRAM STUDI MANAJEMEN ANGKATAN 2019 -

1) Yosafat Kristianus Bao, ${ }^{2}$ )Maria Helena Carolinda Dua Mea program studi.

Berdasarkan fenomena yang ada dan latar belakang masalah diatas maka tujuan penelitian ini adalah untuk mengetahui pengaruh reputasi universitas terhadap keputusan mahasiswa memilih Prodi Manajemen di Universitas Flores, pengaruh biaya kuliah terhadap keputusan mahasiswa memilih Prodi Manajemen di Universitas Flores, pengaruh fasilitas perkuliahan terhadap keputusan mahasiswa memilih Prodi Manajemen di Universitas Flores, dan pengaruh variabel-variabel tersebut secara simultan terhadap keputusan mahasiswa memilih Prodi Manajemen di Universitas Flores.

\section{TINJAUAN PUSTAKA}

Konsep atau teori yang relevan dalam penelitian ini adalah konsep keputusan pembelian, konsep reputasi (merek), biaya pendidikan dan fasilitas.

\subsection{Keputusan pembelian}

Keputusan pembelian merupakan pemikiran dimana individu mengevaluasi berbagai pilihan dan memutuskan pilihan pada suatu produk dari sekian banyak pilihan. Menurut Kotler \& Amstrong (Putra \& Gumanti, 2017), keputusan pembelian adalah tahap dalam proses pengambilan keputusan pembeli di mana konsumen benar-benar membeli.

Menurut Schiffman dan Kanuk (Kartika et al., 2018) keputusan pembelian didefinisikan sebagai sebuah pilihan dari dua tahu lebih alternatif pilihan. Keputusan pembelian adalah sebuah proses dimana konsumen mengenal masalahnya, mencari informasi mengenai produk atau merek tertentu dan mengevaluasi secara baik masingmasing alternatif tersebut dapat memecahkan masalahnya, yang kemudian mengarah kepada keputusan pembelian (Tjiptono, 2017).

Dari pengertian tersebut dapat disimpulkan keputusan pembelian merupakan sebuah proses pengambilan keputusan yang diawali dengan pengenalan masalah kemudian mengevaluasinya dan memutuskan produk yang paling sesuai dengan kebutuhan individu. 
REPUTASI UNIVERSITAS, BIAYA KULIAH, FASILITAS PERKULIAHAN DAN KEPUTUSAN MAHASISWA MEMILIH PROGRAM STUDI MANAJEMEN UNIVERSITAS FLORES: STUDI PADA MAHASISWA PROGRAM STUDI MANAJEMEN ANGKATAN 2019 -

1)Yosafat Kristianus Bao, ${ }^{2}$ )Maria Helena Carolinda Dua Mea

\section{Tahap-Tahap Proses Pengambilan Keputusan Pembelian}

Menurut Kotler dan Amstrong (Putra \& Gumanti, 2017) konsumen akan melalui lima tahap dalam pengambilan keputusan pembelian, yaitu:

1. Pengenalan kebutuhan: Merupakan tahap pertama proses keputusan pembeli, dimana konsumen menyadari suatu masalah atau kebutuhan.

2. Pencarian informasi: Merupakan tahap proses keputusan pembeli dimana konsumen ingin mencari informasi lebih banyak; konsumen mungkin hanya memperbesar perhatian atau melakukan pencarian informasi secara aktif.

3. Evaluasi alternatif: Merupakan tahap proses keputusan pembeli dimana konsumen menggunakan informasi untuk mengevaluasi merek alternatif dalam sekelompok pilihan.

4. Keputusan pembelian : keputusan pembeli tentang merek mana yang paling disukai,

5. Perilaku pasca pembelian: tahap proses keputusan pembeli dimana konsumen mengambil tindakan selanjutnya setelah pembelian, berdasarkan kepuasan atau ketidakpuasan mereka.

\subsection{Reputasi (merek)}

Reputasi adalah suatu nilai yang diberikan kepada individu, institusi atau negara. Reputasi tidak bisa diperoleh dalam waktu singkat karena harus dibangun bertahun-tahun untuk menghasilkan sesuatu yang bisa dinilai oleh publik. Reputasi pada dasarnya adalah nama baik yang dinilai dari pihak eksternal dan internal (Basya dalam(Harahap et al., 2018)).

Menurut Gaotsi dan Wilson (Harahap et al., 2018), reputasi adalah suatu nilai yang diberikan kepada individu, institusi atau negara. Reputasi tidak bisa diperoleh dalam waktu singkat karena harus dibangun bertahun-tahun untuk menghasilkan sesuatu yang bisa dinilai oleh publik. Basya (Harahap et al., 2018) menyatakan bahwa reputasi juga baru bertahan dan sustainable apabila konsistennya perkataan dan perbuatan.

Reputasi menjadi sebuah issue dari sikap dan kepercayaan kepada penghargaan merek/nama, image dan kepuasan serta loyalitas pelanggan (Andreassen, dalam(Harahap et al., 2018)). 
REPUTASI UNIVERSITAS, BIAYA KULIAH, FASILITAS PERKULIAHAN DAN KEPUTUSAN MAHASISWA MEMILIH PROGRAM STUDI MANAJEMEN UNIVERSITAS FLORES: STUDI PADA MAHASISWA PROGRAM STUDI MANAJEMEN ANGKATAN 2019 -

1)Yosafat Kristianus Bao, ${ }^{2}$ )Maria Helena Carolinda Dua Mea

Jadi dapat disimpulkan bahwa reputasi perusahaan/institusi adalah persepsi konsumen mengenai kemampuan perusahaan/institusi dalam memberikan pelayanan terbaik, atau penilaian tentang keadaan masa lalu dan prospek masa yang akan dating mengenai kualitas perusahaan atau produk.

Indikator-indikator reputasi perguruan tinggi yang dipakai dalam penelitian ini (Harahap et al., 2018) antara lain:

1. Kompetensi perguruan tinggi

2. Keunggulan perguruan tinggi

3. Kepercayaan masyarakat pada perguruan tinggi

4. Pengalaman perguruan tinggi

\subsection{Biaya pendidikan}

Biaya pendidikan menurut Matin dalam (Murti, 2019) yaitu seluruh pengeluaran baik yang berupa uang maupun bukan uang sebagai ungkapan rasa tanggung jawab semua pihak (masyarakat, orang tua, dan pemerintah) terhadap pembangunan pendidikan agar tujuan pendidikan yang dicita-citakan tercapai secara efisien dan efektif, yang harus terus digali dari berbagai sumber, dipelihara, dikonsolidasikan, dan ditata secara administratif sehingga dapat digunakan secara efisien dan efektif.

Sedangkan biaya pendidikan menurut Supriadi (2007) (dalam (Murti, 2019), merupakan "salah satu komponen instrumental (instrumental input) yang sangat penting dalam penyelenggaraan pendidikan. Dapat dikatakan bahwa proses pendidikan tidak akan dapat berjalan tanpa dukungan biaya”.

Oleh karena itu pendidikan tidak dapat terhindar dari adanya suatu biaya karena tanpa dukungan biaya, proses pendidikan tidak dapat berjalan dengan lancar. Biaya pendidikan merupakan keseluruhan pengorbanan finansial yang dikeluarkan oleh konsumen (orang tua mahasiswa atau mahasiswi) untuk keperluan selama menempuh pendidikan dari awal sampai berakhirnya pendidikan. Baik itu biaya registrasi dan sks tiap semester, biaya sumbangan pembangunan gedung, dana kesejahteraan dan fasilitas mahasiswa per semester, dan biaya-biaya perkuliahan lainnya yang meliputi biaya pengembangan dan pembiayaan kegiatan kurikuler dan ekstra kurikuler, biaya buku peralatan, biaya ujian negara, serta biaya-biaya pendidikan lainnya yang digunakan untuk menunjang 
REPUTASI UNIVERSITAS, BIAYA KULIAH, FASILITAS PERKULIAHAN DAN KEPUTUSAN MAHASISWA MEMILIH PROGRAM STUDI MANAJEMEN UNIVERSITAS FLORES: STUDI PADA MAHASISWA PROGRAM STUDI MANAJEMEN ANGKATAN 2019 -

1)Yosafat Kristianus Bao, ${ }^{2}$ )Maria Helena Carolinda Dua Mea perkuliahan (Murti, 2019).

Handayani (dalam (Murti, 2019) menyatakan bahwa persepsi calon mahasiswa terhadap biaya kuliah ada beberapa dimensi yang relevan diantaranya uang gedung dapat dijangkau, biaya SPP sesuai kualitas pendidikan dan biaya tambahan (praktikum dan lain-lain) tidak membebani.

Dalam penelitian ini, indikator yang digunakan untuk biaya pendidikan (Murti, 2019) adalah sebagai berikut:

1. Biaya registrasi pendidikan

2. Beban SKS per semester

3. Pembiayaan kegiatan kurikuler atau ekstra kurikuler

\subsection{Fasilitas}

Fasilitas merupakan segala sesuatu yang memudahkan dan memperlancar suatu kegiatan. Fasilitas pendidikan dapat dikelompokkan menjadi dua, yaitu sarana pendidikan dan prasarana pendidikan. Menurut (Kurliyatin et al., 2017), (Bafadal, 2008), sarana pendidikan adalah semua perangkat peralatan, bahan, dan perabot yang secara langsung digunakan dalam proses pendidikan di sekolah, sedangkan prasarana pendidikan adalah semua perangkat kelengkapan dasar yang secara tidak langsung menunjang pelaksanaan proses pendidikan di sekolah.

(Bafadal, 2008) mengklasifikasikan prasarana pendidikan menjadi dua macam yaitu prasarana pendidikan yang secara langsung digunakan untuk proses belajar mengajar, seperti ruang teori, ruang perpustakaan, ruang praktik keterampilan, dan ruang laboratorium, dan prasarana sekolah yang keberadaanya tidak digunakan untuk proses belajar mengajar, tetapi secara langsung sangat menunjang terjadinya proses belajar mengajar. Contohnya ruang kantor, kantin sekolah, tanah dan jalan menuju sekolah, kamar kecil, ruang usaha kesehatan sekolah, ruang guru, ruang kepala sekolah, dan tempat parker kendaraan.

Berdasarkan pengertian di atas maka dapat di simpulkan bahwa fasilitas pendidikan adalah segala sarana dan prasana yang tersedia guna memudahkan dan mendukung aktifitas pembelajaran. Fasilitas pendidikan yang memadai dan lengkap dibutuhkan oleh lembaga pendidikan guna mendukung proses kegiatan belajar mengajar baik di tingkat pendidikan dasar maupun pendidikan tinggi. Mahasiswa akan merasa nyaman dalam menempuh pendidikan apabila semua fasilitas yang diperlukan tersedia dan dapat digunakan 
REPUTASI UNIVERSITAS, BIAYA KULIAH, FASILITAS PERKULIAHAN DAN KEPUTUSAN MAHASISWA MEMILIH PROGRAM STUDI MANAJEMEN UNIVERSITAS FLORES: STUDI PADA MAHASISWA PROGRAM STUDI MANAJEMEN ANGKATAN 2019 -

1)Yosafat Kristianus Bao, $\left.{ }^{2}\right)$ Maria Helena Carolinda Dua Mea

sebagaimana fungsinya.

Adapun indikator dari variabel fasilitas perkuliahan adalah (Azhari \& Kurniady, 2016):

1. Kondisi fasilitas fisik

2. Gedung perkuliahan

3. Fasilitas pendukung perkuliahan

\subsection{Model penelitian dan pengembangan hipotesis}

Dari hasil pemaparan konsep di atas, maka peta jalan penelitian adalah sebagai berikut:

Gambar 1. Model penelitian

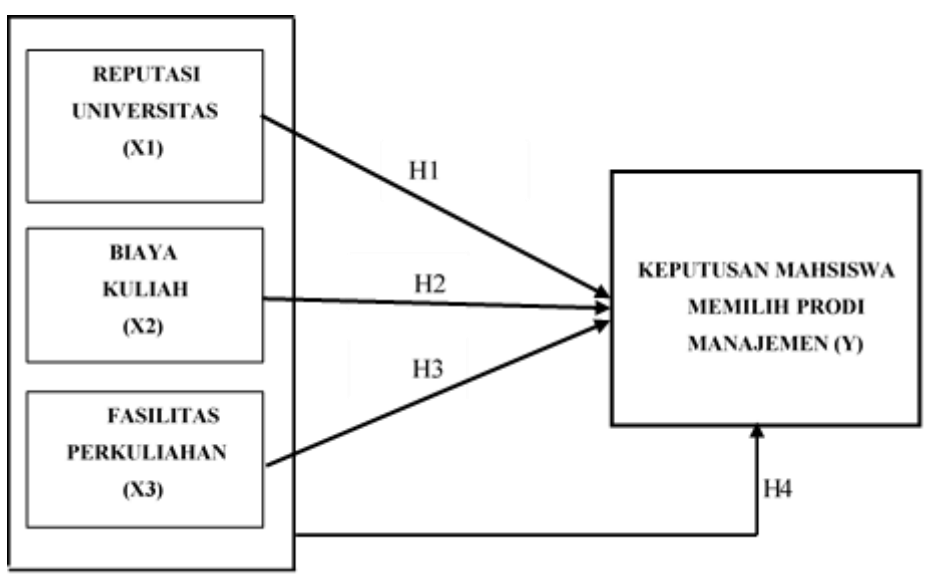

Sumber: Olahan Penulis, 2020

\section{Keterangan:}

H1 : Reputasi Universitas berpengaruh terhadap Keputusan Mahasiswa

H2 : Biaya Kuliah berpengaruh terhadap Keputusan Mahasiswa

H3 : Fasilitas Perkuliahan berpengaruh terhadap Keputusan Mahasiswa

H4 : Reputasi Universitas, Biaya Kuliah, dan Fasilitas Perkuliahan berpengaruh secara simultan terhadap Keputusan Mahasiswa

\section{METODE PENELITIAN}

Penelitian ini menggunakan metode penelitian dengan pendekatan kuantitatif. Pada penelitian ini metode pengumpulan data primer dilakukan dengan metode survei. Penelitian ini menekankan pada pengolahan data dalam pengujian variabel sehingga dapat diperoleh signifikansi hubungan antara variabel-variabel yang diteliti. Pada penelitian ini variabel yang dipertimbangkan untuk dianalisis dapat dilihat pada tabel berikut: 
REPUTASI UNIVERSITAS, BIAYA KULIAH, FASILITAS PERKULIAHAN DAN KEPUTUSAN MAHASISWA MEMILIH PROGRAM STUDI MANAJEMEN UNIVERSITAS FLORES: STUDI PADA MAHASISWA PROGRAM STUDI MANAJEMEN ANGKATAN 2019 -

1)Yosafat Kristianus Bao, ${ }^{2}$ )Maria Helena Carolinda Dua Mea

Tabel 3.1

Definisi Operasional Variabel

\begin{tabular}{|c|c|c|c|}
\hline No & Variabel & Indikator & $\begin{array}{l}\text { Skala } \\
\text { Pengukuran }\end{array}$ \\
\hline 1 & $\begin{array}{l}\text { Reputasi } \\
\text { Universitas }\end{array}$ & $\begin{array}{ll}\text { a. Kompetensi perguruan } \\
\text { tinggi } \\
\text { b. Keunggulan perguruan } \\
\text { tinggi } \\
\text { c. Kepercayaan } \\
\text { masyarakat pada } \\
\text { perguruan tinggi } \\
\text { d. Pengalaman perguruan } \\
\text { tinggi } \\
\text { (Gaotsi dan Wilson } \\
\text { dalam (Harahap et al., } \\
\text { 2018)) }\end{array}$ & $5,4,3,2,1$ \\
\hline 2 & $\begin{array}{l}\text { Biaya } \\
\text { Kuliah }\end{array}$ & $\begin{array}{l}\text { a. Biaya registrasi } \\
\text { pendidikan } \\
\text { b. Biaya beban sks per } \\
\text { semester } \\
\text { c. Biaya kegiatan } \\
\text { mahasiswa } \\
\text { (Supriadi (2007) dalam } \\
\text { (Murti, 2019) }\end{array}$ & $5,4,3,2,1$ \\
\hline 3 & $\begin{array}{l}\text { Fasilitas } \\
\text { Perkuliahan }\end{array}$ & $\begin{array}{l}\text { a. Kondisi fasilitas fisik } \\
\text { b. Gedung perkuliahan } \\
\text { c. Fasilitas pendukung } \\
\text { perkuliahan } \\
\text { (Bafadal, 2008) }\end{array}$ & $5,4,3,2,1$ \\
\hline 4 & $\begin{array}{l}\text { Keputusan } \\
\text { Mahasiswa }\end{array}$ & $\begin{array}{ll}\text { a. } & \text { Tujuan } \\
\text { b. } & \text { Identifikasi Alternatif } \\
\text { c. } & \text { Faktor yang tidak dapat } \\
& \text { diketahui sebelumnya } \\
\text { d. } & \text { Dibutuhkan sarana } \\
& \text { untuk mengukur hasil } \\
& \text { yang dicapai ( } \\
& \text { Atmosudirdjo, dalam } \\
& \text { (Harahap et al., 2018) }\end{array}$ & $5,4,3,2,1$ \\
\hline
\end{tabular}

Penelitian ini dilakukan di Universitas Flores, Ende. Populasi dalam penelitian ini adalah seluruh mahasiswa Program Studi Manajemen, Fakultas Ekonomi Universitas Flores angkatan 2019 yang berjumlah 131 orang.

Untuk menentukan berapa minimal jumlah sampel yang dibutuhkan jika jumlah ukuran populasi digunakan, maka digunakan rumus Slovin dengan tingkat kesalahan 10\%. Maka sampel dalam penelitian ini adalah 99 orang mahasiswa Program Studi Manajemen Universitas Flores angkatan 2019.

Teknik pengumpulan sampel yang digunakan adalah metode pengambilan sampel yang bersifat tidak acak (non probabilty sampling technique) dengan jenisnya yaitu purposive 
REPUTASI UNIVERSITAS, BIAYA KULIAH, FASILITAS PERKULIAHAN DAN KEPUTUSAN MAHASISWA MEMILIH PROGRAM STUDI MANAJEMEN UNIVERSITAS FLORES: STUDI PADA MAHASISWA PROGRAM STUDI MANAJEMEN ANGKATAN 2019 -

1)Yosafat Kristianus Bao, ${ }^{2}$ )Maria Helena Carolinda Dua Mea

sampling. Teknik pengumpulan data yang digunakan menggunakan kuisioner, dan jawaban responden dinilai berdasarkan skala Likert 1 sampai 5.

Uji validitas yang digunakan ialah dengan analisis item, dimana setiap nilai yang ada pada setiap butir pertanyaan dikorelasikan dengan nilai total seluruh butir pertanyaan untuk suatu variabel dengan menggunakan rumus korelasi product moment. Uji Reliabilitas menggunakan uji alpha cronbach.

Metode analisis yang digunakan adalah analisis regresi. Pengujian hipotesis yang dilakukan pada penelitian ini terdiri dari uji t hitung (uji parsial), uji F hitung (uji simultan), dan analisis koefisien determinasi $\left(\mathrm{R}^{2}\right) .1$

\section{HASIL DAN PEMBAHASAN}

\subsection{Reputasi Universitas dan Keputusan Mahasiswa Memilih Prodi Manajemen di Universitas Flores}

Reputasi menjadi sangat penting bagi mahasiswa dalam memilih program studi dalam melanjutkan pendidikannya. Perguruan tinggi yang memiliki reputasi yang baik, pasti memiliki kualitas yang baik dalam menghasilkan output. Dalam hal ini terkait kepribadian perguruan tinggi, kompetensi perguruan tinggi, keunggulan perguruan tinggi, kepercayaan masyarakat pada perguruan tinggi, serta pengalaman perguruan tinggi menjadi suatu gambaran bagaimana gambaran dari reputasi suatu perguruan tinggi. Hal ini, sejalan dengan pernyataan Deephouse (dalam (Suriyani, 2016) bahwa reputasi juga sering didefinisikan sebagai keunggulan kompetitif terpenting yang dimiliki oleh perusahaan. Reputasi merupakan kumpulan penilaian pihak luar dalam jangka panjang terhadap seberapa baik komitmen perusahaan untuk memenuhi harapan stakeholders. Mazzarol dan Soutar (dalam (Suriyani, 2016) menyebut "strong reputation" sebagai satu kompetensi kunci bagi institusi pendidikan untuk sukses bersaing di pasar global.

Hasil penelitian menunjukkan bahwa terdapat pengaruh positif dan signifikan antara reputasi universitas terhadap keputusan mahasiswa memilih Prodi Manajemen di Universitas Flores. Hal ini ditunjukkan dengan nilai thitung sebesar 19,794 dengan taraf signifikansi sebesar 0,000 atau nilai sig < 0,05 maka hipotesis pertama yang menyatakan "reputasi universitas berpengaruh terhadap keputusan mahasiswa memilih Prodi Manajemen di Universitas Flores” diterima. 
REPUTASI UNIVERSITAS, BIAYA KULIAH, FASILITAS PERKULIAHAN DAN KEPUTUSAN MAHASISWA MEMILIH PROGRAM STUDI MANAJEMEN UNIVERSITAS FLORES: STUDI PADA MAHASISWA PROGRAM STUDI MANAJEMEN ANGKATAN 2019 -

1)Yosafat Kristianus Bao, ${ }^{2}$ )Maria Helena Carolinda Dua Mea

\subsection{Biaya Kuliah dan Keputusan Mahasiswa Memilih Prodi Manajemen di Universitas} Flores

Hasil penelitian yang dilakukan oleh (Rahardjo \& Firdaus, 2015) dan (Suriyani, 2016) menunjukkan bahwa biaya pendidikan mempunyai pengaruh yang positif dalam keputusan mahasiswa melanjutkan studi. Akan tetapi penelitian ini menunjukkan bahwa biaya kuliah tidak berpengaruh terhadap keputusan mahasiswa memilih Prodi Manajemen di Universitas Flores. Hal ini ditunjukkan dengan nilai thitung sebesar 0,887 dengan taraf signifikansi sebesar 0,377 atau sig > 0,05. Dengan demikian hipotesis kedua yang menyatakan "biaya kuliah berpengaruh terhadap keputusan mahasiswa memilih Prodi Manajemen di Universitas Flores" ditolak.

Dari hasil analisis data yang diolah pada penelitian ini, nilai koefisien biaya kuliah 0,023 menunjukkan tanda positif. Hal ini berarti menunjukkan bahwa apabila terjadi peningkatan biaya kuliah akan memberikan pengaruh meningkatnya keputusan mahasiswa memilih Prodi Manajemen di Universitas Flores. Pada dasarnya sifat elastisitas dari komoditi pendidikan tinggi adalah inelastis dimana nilai mutlaknya kurang dari 1, jadi permintaan pendidikan tinggi tidak responsif terhadap perubahan harga. Sehingga ketika pihak Prodi Manajemen di Universitas Flores menaikkan atau menurunkan biaya pendidikan yang dibebankan kepada mahasiswa, tidak akan berpengaruh terhadap keputusan mereka untuk memilih pendidikan pada Prodi Manajemen di Universitas Flores.

Penelitian ini sejalan dengan teori yang disampaikan Matin (dalam (Atmaja et al., 2016) yaitu biaya pendidikan adalah seluruh pengeluaran baik yang berupa uang maupun bukan uang sebagai ungkapan rasa tanggung jawab semua pihak (masyarakat, orang tua, dan pemerintah) terhadap pembangunan pendidikan agar tujuan pendidikan yang dicitacitakan tercapai secara efisien dan efektif, yang harus terus digali dari berbagai sumber, dipelihara, dikonsolidasikan, dan ditata secara administratif sehingga dapat digunakan secara efisien dan efektif. 
REPUTASI UNIVERSITAS, BIAYA KULIAH, FASILITAS PERKULIAHAN DAN KEPUTUSAN MAHASISWA MEMILIH PROGRAM STUDI MANAJEMEN UNIVERSITAS FLORES: STUDI PADA MAHASISWA PROGRAM STUDI MANAJEMEN ANGKATAN 2019 -

1)Yosafat Kristianus Bao, ${ }^{2}$ )Maria Helena Carolinda Dua Mea

\subsection{Fasilitas Perkuliahan dan Keputusan Mahasiswa Memilih Prodi Manajemen di Universitas Flores}

Fasilitas perkuliahan yang diberikan oleh suatu perguruan tinggi dapat dilihat dari kondisi fasilitas fisik, kondisi gedung perkuliahan, dan fasilitas pendukung perkuliahan, dengan memberikan fasilitas pendidikan yang baik, tentunya akan menarik perhatian dalam memilih program studi yang ditawarkan perguruan tinggi tersebut. Sesuai dengan yang dijelaskan oleh (Bafadal, 2008), (Kurliyatin et al., 2017) dan (Rahardjo \& Firdaus, 2015) serta (Fakhri et al., 2017) bahwa untuk belajar yang baik hendaknya tersedia fasilitas belajar yang memadai, antara lain ruang tempat belajar, penerangan cukup, buku-buku pegangan, dan kelengkapan peralatan belajar. Fasilitas belajar pada prinsipnya adalah segala sesuatu yang memudahkan untuk belajar.

Hasil penelitian menunjukkan bahwa terdapat pengaruh positif dan signifikan antara fasilitas perkuliahan terhadap keputusan mahasiswa memilih Prodi Manajemen di Universitas Flores. Hal ini ditunjukkan dengan nilai thitung sebesar 5,295 dengan taraf signifikansi sebesar 0,000 atau nilai sig < 0,05 maka hipotesis ketiga yang menyatakan "fasilitas perkuliahan berpengaruh terhadap keputusan mahasiswa memilih Prodi Manajemen di Universitas Flores" diterima.

\subsection{Reputasi Universitas, Biaya Kuliah, Fasilitas Perkuliahan dan Keputusan Mahasiswa Memilih Prodi Manajemen di Universitas Flores}

Keputusan mahasiswa merupakan kemampuan atau tindakan mahasiswa dalam usahanya untuk memilih Prodi Manajemen di Universitas Flores. Keputusan mahasiswa tersebut sama dengan keputusan pembelian seorang konsumen pada suatu produk/jasa yang bersifat kompleks karena dipengaruhi oleh berbagai faktor-faktor yang mempengaruhi dan kecenderungan untuk saling berinteraksi.

Hasil analisis menunjukkan bahwa terdapat pengaruh positif dan signifikan antara reputasi universitas, biaya kuliah, dan fasilitas perkuliahan secara bersama-sama terhadap keputusan mahasiswa memilih Prodi Manajemen di Universitas Flores. Hal ini ditunjukkan dengan hasil uji $\mathrm{F}$ yang mempunyai nilai signifikansi 0,000 atau $<0,05$.

Nilai R2 sebesar 0, 965 atau 96,5\%, jadi dapat dikatakan bahwa 96,5\% keputusan mahasiswa dipengaruhi oleh reputasi universitas, biaya kuliah, dan fasilitas perkuliahan. Sedangkan sisanya 3,5\% dipengaruhi variabel lain yang tidak diteliti dalam penelitian ini. 
REPUTASI UNIVERSITAS, BIAYA KULIAH, FASILITAS PERKULIAHAN DAN KEPUTUSAN MAHASISWA MEMILIH PROGRAM STUDI MANAJEMEN UNIVERSITAS FLORES: STUDI PADA MAHASISWA PROGRAM STUDI MANAJEMEN ANGKATAN 2019 -

1)Yosafat Kristianus Bao, ${ }^{2}$ )Maria Helena Carolinda Dua Mea

\section{KESIMPULAN DAN SARAN}

Berdasarkan hasil analisis dan pembahasan di atas, maka dapat ditarik beberapa kesimpulan dari hasil penelitian ini, antara lain:

1. Reputasi universitas berpengaruh signifikan terhadap keputusan mahasiswa memilih Prodi Manajemen,

2. Biaya kuliah tidak berpengaruh signifikan terhadap keputusan mahasiswa memilih Prodi Manajemen,

3. Fasilitas perkuliahan berpengaruh signifikan terhadap keputusan mahasiswa memilih Prodi Manajemen,

4. Secara simultan reputasi universitas, biaya kuliah, dan fasilitas perkuliahan berpengaruh terhadap keputusan mahasiswa memilih Prodi Manajemen.

Saran yang dapat peneliti berikan untuk institusi Universitas Flores dan Program Studi

Manajemen adalah sebagai berikut:

a. Menganalisis biaya yang baik bukan hanya melakukan pendekatan finansial semata, tetapi juga harus memperhatikan faktor-faktor lainnya seperti penerimaan kegiatan oleh masyarakat (socially acceptable), menguntungkan secara ekonomi (economically beneficial), dukungan secara politis (politically dependable), dapat dilaksanakan secara teknis (technically practicable), dan dapat dikelola secara organisatoris (organizationally manageable).

b. Lebih memperhatikan biaya dan fasilitas mahasiswa per semester, dan biaya-biaya perkuliahan lainnya yang meliputi biaya pengembangan dan pembiayaan kegiatan kurikuler dan ekstra kurikuler, biaya buku peralatan, serta biaya-biaya pendidikan lainnya yang tidak terbebani.

\section{REFERENSI}

Atmaja, T. E. R., Harun, C. Z., \& Ibrahim, S. (2016). Analisis Penetapan Standar Biaya Pendidikan. Jurnal Administrasi Pendidikan.

Azhari, U. L., \& Kurniady, D. A. (2016). Manajemen Pembiayaan Pendidikan, Fasilitas Pembelajaran, Dan Mutu Sekolah. Jurnal Administrasi Pendidikan.

Bafadal, I. (2008). Manajemen Perlengkapan Sekolah: Teori dan Aplikasinya. In Bumi Aksara. https://doi.org/2008 
REPUTASI UNIVERSITAS, BIAYA KULIAH, FASILITAS PERKULIAHAN DAN KEPUTUSAN MAHASISWA MEMILIH PROGRAM STUDI MANAJEMEN UNIVERSITAS FLORES: STUDI PADA MAHASISWA PROGRAM STUDI MANAJEMEN ANGKATAN 2019 -

1)Yosafat Kristianus Bao, ${ }^{2}$ Maria Helena Carolinda Dua Mea

Evridawati, B., Yufiarti, \& Yetti, E. (2020). The Cognitive Style and Attachment on Early Childhood Speech Skills. JPUD - Jurnal Pendidikan Usia Dini. https://doi.org/10.21009/jpud.141.03

Fakhri, M., Gilang, A., \& Ratnayu, N. (2017). Perguruan Tinggi Swasta Universitas Telkom ( Studi Pada Mahasiswa S1 Administrasi Bisnis Fakultas Komunikasi Dan Bisnis Univeritas Telkom Angkatan 2016). Jurnal Ekonomi, Bisnis Dan Entreneurship.

Harahap, D. A., Hurriyati, R., Gaffar, V., Wibowo, L. A., \& Amanah, D. (2018). Effect of Word of Mouth on Students Decision to Choose Studies in College. https://doi.org/10.5220/0007090007930797

Kartika, D. A., Hurriyati, R., \& Razati, G. (2018). Gambaran Kepribadian Merek Terhadap Keputusan Pembelian Produk Bedak Tabur Pixy Di Indonesia. Journal of Business Management Education (JBME). https://doi.org/10.17509/jbme.v3i3.14310

Kurliyatin, A., Bafadal, I., \& Zulkarnain, W. (2017). Hubungan Citra Sekolah, Pelayanan Prima, Harapan Orangtua, dan Rasa Bangga Orangtua dengan Keputusan Orangtua Menentukan Sekolah untuk Anaknya. Ilmu Pendidikan: Jurnal Kajian Teori Dan Praktik Kependidikan. https://doi.org/10.17977/um027v2i22017p129

Murti, T. K. (2019). Pengaruh Brand Image, Promosi dan Biaya Pendidikan Terhadap Keputusan Mahasiswa Melanjutkan Studi Pada Program Studi Pendidikan Ekonomi. Edunomic Jurnal Pendidikan Ekonomi. https://doi.org/10.33603/ejpe.v7i2.1969

Putra, S. W., \& Gumanti, T. A. (2017). The Influence of Brand Equity and Green Marketing on Consumer' s Decision to Purchase Honda Beat Series in Surabaya. Jurnal of Management and Marketing Review.

Rahardjo, S., \& Firdaus, M. R. (2015). Analisis Pengaruh Bauran Pemasaran Status Mahasiswa Dalam Memilih Kuliah (Studi Pada Lembaga Pendidikan Dan Pengembangan Profesi Indonesia (LP3I) Business College- Cabang Banjarmasin). Jurnal Wawasan Manajemen.

Suriyani, K. W. (2016). Faktor-Faktor yang Mempengaruhi Keputusan Mahasiswa dalam Memilih Jurusan Akuntansi Program S1 di Universitas Pendidikan Ganesha. Ekuitas: Jurnal Pendidikan Ekonomi. https://doi.org/10.23887/ekuitas.v4i2.12792

Tjiptono. (2017). Analisis Perbedaan Kualitas Pelayanan \& Kepuasan. Young Consumers. https://doi.org/10.1108/YC-05-2017-00697 